\title{
Knowledge of Stem Cells among Pregnant Women in Rural Areas of Puducherry
}

\author{
Santha D Arumugam ${ }^{1}$, Joice Vinodine ${ }^{2}$, Balavaishnavi Guna ${ }^{3}$, Parameshwari Gobinathan ${ }^{4}$
}

\begin{abstract}
Stem cells are unique cells, as they have the potential to undergo repair and regeneration into a variety of distinct cell types of the body. These cells are of great importance in today's regenerative medicine and can be isolated from specific tissues of the body including oral cavity. Especially, stem cells obtained from the placenta and umbilical cord that were considered to be biologic waste can be used in the treatment of cancerous conditions also. Moreover, the recent past has plenty of studies carried out in pulpal stem cells from the dental tissues. Hence, the present study was conducted to assess the level of awareness and knowledge about different sources of stem cells and its importance among expectant mothers in rural areas of Puducherry population. Through this study, the knowledge of stem cells will be emphasized among the pregnant women.
\end{abstract}

Keywords: Dental stem cells, Pregnant women, Stem cells.

Journal of Scientific Dentistry (2020): 10.5005/jp-journals-10083-0934

\section{INTRODUCTION}

Stem cells possess the ability to repair and regenerate into several cell types in the body, such as tooth, bone, cartilages, skin, adipose tissues, and glands. Isolation of these stem cells can be done from certain tissues within body, including oral cavity, and the blood in the umbilical cord is the richest source of stem cells. The stem cells are of two main types: the embryonic stem cells and the adult stem cells. Embryonic stem cells are otherwise known as somatic stem cells that represent undifferentiated cells present throughout the body after embryonic development, which can undergo multiplication through the process of cell division thereby replenish the dying cells and leading to regeneration of the damaged tissues. These stem cells are obtained from certain tissues of the body, including oral cavity, out of which the umbilical cord blood has its own importance, as it contains rich source of stem cells. Until recently, the cord blood that is retained in the placenta and the umbilical cord present after birth was considered as medical waste, and now the importance of umbilical cord has been reached to that level of even treating the life-threatening malignant disease.

\section{Aim and Objective}

To assess the knowledge about stem cells among expectant mothers in rural areas of Puducherry population.

\section{Materials and Methods}

The study participants consisted of pregnant women who visited the medical and dental hospital. It was a questionnaire-based study with 10 questions ( 9 questions related to knowledge and one question related to attitude).

\begin{tabular}{|c|c|c|}
\hline \multicolumn{3}{|c|}{$\begin{array}{l}{ }^{1-4} \text { Department of Oral and Maxillc } \\
\text { biology, Indira Gandhi Institute } \\
\text { Vidyapeeth, Puducherry, India }\end{array}$} \\
\hline \multicolumn{3}{|c|}{$\begin{array}{l}\text { Corresponding Author: Santha D Arumugam, Department of Oral and } \\
\text { Maxillofacial Pathology and Oral Microbiology, Indira Gandhi Institute } \\
\text { of Dental Sciences, Sri Balaji Vidyapeeth, Puducherry, India, Phone: } \\
\text { +919443634624, e-mail: drsantha73@gmail.com }\end{array}$} \\
\hline \multirow{3}{*}{\multicolumn{3}{|c|}{$\begin{array}{l}\text { How to cite this article: Aru } \\
\text { P. Knowledge of Stem Cells } \\
\text { Puducherry. J Sci Dent } 2020 \\
\text { Source of support: Nil } \\
\text { Conflict of interest: None }\end{array}$}} \\
\hline & & \\
\hline & & \\
\hline \multicolumn{3}{|c|}{ RESUlts } \\
\hline S. no. & Question no. & Percentage \\
\hline 1 & Know about stem cells & 60 \\
\hline 2 & Use of stem cells & 98 \\
\hline 3 & Stem cell therapy & 95 \\
\hline 4 & Collection of stem cells & 92 \\
\hline 5 & Stem cells from umbilical cord & 92 \\
\hline 6 & Stem cells from tooth & 34 \\
\hline 7 & Stem cell banks & 35 \\
\hline 8 & Consultation & 39 \\
\hline 9 & Storage and donation & 88 \\
\hline 10 & To know more & 88 \\
\hline
\end{tabular}

(-) The Author(s). 2020 Open Access This article is distributed under the terms of the Creative Commons Attribution 4.0 International License (https://creativecommons. org/licenses/by-nc/4.0/), which permits unrestricted use, distribution, and non-commercial reproduction in any medium, provided you give appropriate credit to the original author(s) and the source, provide a link to the Creative Commons license, and indicate if changes were made. The Creative Commons Public Domain Dedication waiver (http://creativecommons.org/publicdomain/zero/1.0/) applies to the data made available in this article, unless otherwise stated. 


\section{Discussion}

Stem cells are unspecialized cells although immature have the potential to develop into different cell lineages by differentiation. ${ }^{1}$ Their ability for self-renewal and differentiation makes them play a vital role in the repair of tissues and organs. ${ }^{2}$ Recently, studies reveal that the oral tissues serve as a rich source of stem cells. In dentistry, regeneration of the missing tissues in the oral cavity has been the main focus. Adult stem cells also called as somatic or postnatal stem cells are present in various tissues and organs. Recent studies in dentistry have revealed various sources for stem cells within the oral and maxillofacial region that reside in special site of each tissue called the stem cell niche. The adult stem cells in dental tissues are mainly of two types, namely, epithelial stem cells and mesenchymal-like cells. ${ }^{1}$ There are various sources of dental stem cells in orofacial region such as stem cells of dental follicle, stem cells of dental pulp, stem cells of apical papilla, periodontal ligament stem cells, progenitor cells of tooth germ, and immature dental pulp stem cells. ${ }^{3}$ The niche is present in the cervical loop of tooth apex which differentiates into enamel-producing cells, the ameloblasts. Regeneration of mesenchymal stem cells like periodontal tissues and dental pulp can form reparative dentin. ${ }^{1}$

The human periodontal ligament contain post-natal multipotent stem cells that serve as reservoir of stem cells and can be expanded ex vivo. ${ }^{4}$ The replacement of missing teeth in patients by the development of bioengineered teeth was possible because of stem cell technologies. ${ }^{5}$ The cultured tooth bud cells can give rise to these bioengineered teeth. Plenty of multipotent immature stem cells are present in deciduous teeth, which can form dentin-like structures although not a complete dentin-pulp complex. These tooth developed through bio-engineering technologies exhibit well-defined odontoblasts, predentin, dentin, and pulp chambers. It shows stellate reticulum, stratum intermedium, ameloblasts, dental enamel as well as putative Hertwig's root sheath epithelium, thus morphologically mimicking structures of the enamel organ. ${ }^{6}$

The dental stem cells first obtained from dental pulp were dental pulp stem cells (DPSCs) isolated by enzymatic digestion of the pulp tissue of the human-impacted third molars. DPSCs can differentiate into adipocyte, chondrocyte, and osteocyte cell lineages, show expression for epithelial markers characteristically similar to neural stem cells. They have the ability to differentiate into vascular endothelial or neural cells in vitro. ${ }^{7}$ After oral surgery procedures, the human dental tissues are disposed considering them as medical waste, but these dental tissues are easy to obtain and are rich source of adult mesenchymal stem cells. The "medicine from disposed tissues" referred as "waste medicine" is a branch of regenerative medicine. ${ }^{8}$
Dental stem cell banking refers to the process of stem cell storage acquired from deciduous teeth and wisdom teeth of patients, which reflects the ability of dental stem cell-based regenerative therapy. ${ }^{9}$ Tissues containing stem cells can be acquired from patients and cryopreserved for several years to retain their regenerative capacity. These dental stem cells are well tolerated by the immune system and can be isolated from the cryopreserved tissue/tooth for future regenerative therapies when required. ${ }^{10}$

\section{Conclusion}

This questionnaire study revealed an average level (60\%) of awareness about stem cells among pregnant women. This urges a need to spread more knowledge about the advances in applications, storage, banking and guidelines related to dental stem cells. Similar surveys and research must be conducted at different levels to spread the awareness globally so that everyone can gain the benefits in the future.

\section{References}

1. Egusa H, Sonoyama W, Nishimura M, Atsuta I, Akiyama K. Stem cells in dentistry-part I: stem cell sources. J Prosthodon Res 2012;56: 151-165.

2. Egusa H, Sonoyama W, Nishimura M, Atsuta I, Akiyama K. Stem cells in dentistry-part II: clinical applications. J Prosthodon Res 2012;56:229-248.

3. Chitroda PK, Katti G, Attar NM, Shahbaz S, Sreenivasarao G, Patil A. Stem cells in dentistry: a study regarding awareness of stem cells among dental professionals. Indian J Dent Res 2017;28:711-716.

4. Narang S, Sehgal N. Stem cells: a potential regenerative future in dentistry. Indian J Hum Genet 2012;18:150-154.

5. Paz AG, Maghaireh H, Mangano FG. Stem cells in dentistry: types of Intra- and extraoral tissue-derived stem cells and clinical applications. Stem Cells Int 2018;2018:4313610.

6. Cheng PH, Snyder B, Fillos D, Ibegbu CC, Huang AH, Chan AW. Postnatal stem/progenitor cells derived from the dental pulp of adult chimpanzee. BMC Cell Biol 2008;9:20.

7. Chalisserry EP, Nam SY, Park SH, Anil S. Therapeutic potential of dental stem cells. J Tissue Eng 2017;8:1-17.

8. Tatullo M. About stem cell research in dentistry: many doubts and too many pitfalls still affect the regenerative dentistry. Int J Med Sci 2018;15(14):1616-1618.

9. Kaku M, Kamada H, Kawata T, Koseki H, Abedini S, Kojima S, et al. Cryopreservation of periodontal ligament cells with magnetic field for tooth banking. Cryobiology 2010;61(1):73-78.

10. Tirino V, Paino F, d'Aquino R, Desiderio V, De Rosa A, Papaccio G. Methods for the identification, characterization and banking of human DPSCs: current strategies and perspectives. Stem Cell Rev 2011;7(3):608-615. 